\title{
MEMAKNAI KEKERASAN ORANG MADURA DI PERANTAUAN: STUDI SOSIAL KEBERAGAMAAN MASYARAKAT MADURA DI SEMAMPIR JAWA TIMUR
}

\author{
PURPOSE MADURA VIOLENCE IN OVERSEAS: \\ SOCIAL STUDY OF MADURA SOCIETY IN SEMAMPIR, \\ EAST JAVA
}

\author{
Ahmad Fatoni \\ Dosen Fakultas Agama Islam Universitas Muhammadiyah Malang \\ tonscollect@yahoo.com \\ Artikel diterima 06 November 2019, diseleksi 16 April 2020, \\ dan disetujui 23 Oktober 2020
}

\begin{abstract}
The purpose of this study is to find out the forms of violence perpetrated by Madurese in Semampir, such as cases of murder, gambling, theft, and the habit of carrying sharp weapons. These cases make Semampir received a label as a familiar area with violence. This study uses a descriptive exploratory approach. With the analysis of the social facts, violent behavior committed by Madurese in Semampir is known, that it is triggered by several factors. The most prominent factor is the exaggeration of self-esteem that is too excessive. Second, the process of interaction between overseas Madurese in multi-ethnic areas, does have sociocultural characteristics that tend to be hard, both physically and psychologically. Third, the religious system of Madurese in Semampir is more dominated by ceremonial events so that it cannot be used as a tool for social control maximally. This article confirms that the portrait of the Madurese in Semampir suggests the complexity of their lives, which are full of attraction between various forces, from religion, economy, education, culture, and politics.
\end{abstract}

Keywords: Violence, Overseas Madura, Cultural System, Social Control.

\begin{abstract}
Abstrak
Tujuan dari penelitian ini adalah untuk mengetahui bentuk-bentuk kekerasan yang dilakukan orang Madura di Semampir, seperti kasus pembunuhan, perjudian, pencurian, dan kebiasaan membawa senjata tajam. Kasus-kasus tersebut menjadikan Semampir mendapat label sebagai wilayah yang akrab dengan tindak kekerasan. Penelitian ini menggunakan pendekatan deskriptif eksploratif. Melalui analisa fakta sosial, perilaku kekerasan yang dilakukan orang Madura di Semampir diketahui sebabnya, yaitu karena dipicu oleh beberapa faktor. Faktor yang paling menonjol adalah sikap mengagungkan harga diri yang terlalu berlebih-lebihan. Kedua, proses interaksi orang Madura di daerah perantauan yang multietnis memang cenderung memiliki karakteristik sosial budaya yang cenderung keras, baik secara fisik maupun psikis. Ketiga, sistem keberagamaan masyarakat Madura di Semampir lebih didominasi oleh acara-acara seremonial sehingga tidak dapat berfungsi sebagai alat kontrol sosial secara maksimal. Artikel ini menegaskan bahwa potret masyarakat Madura di Semampir mengisyaratkan tentang kompleksitas kehidupan mereka yang penuh dengan tarikmenarik antar berbagai kekuatan, dari agama, ekonomi, pendidikan, budaya, dan politik.
\end{abstract}

Kata Kunci: Kekerasan, Madura Perantauan, Sistem Budaya, Kontrol Sosial. 


\section{PENDAHULUAN}

Jika Aceh dikenal sebagai serambi Mekah, maka Madura adalah serambi Madinahnya (Junaidy, 1999). Tak banyak daerah yang mendapat kehormatan dilekati label istimewa ini. Dari kedua atribut tersebut terlihat posisi dan kultur yang sangat khas, yakni kelekatannya dengan tradisi keislaman. Tidaklah aneh jika keseluruhan bangunan hidup dan kehidupan masyarakatnya tidak dapat dilepaskan dari kultur keagamaannya yang teramat khas itu.

Namun oleh etnis lain, masyarakat Madura seringkali dideskripsikan jauh berbeda dengan pandangan orang Madura tentang diri mereka sendiri. Menurut budayawan D. Zawawi Imron, seringkali gambaran tentang masyarakat Madura oleh orang luar bernuansa sangat negatif. Etnis lain biasanya mengilustrasikan masyarakat Madura sebagai kelompok orang-orang yang kasar, suka membunuh, pendendam, mudah tersinggung, dan tidak toleran terhadap orang lain (Junaidy, 1999).

Selain itu, orang luar Madura juga cenderung membayangkan orang-orang Madura sebagai pekerja keras, gigih, tekun, dan sekaligus menyimpan banyak stereotip "kengerian" bagi orang-orang yang bukan Madura. Sejak dulu orang Madura memang dikenal pemberani dan kasar bahkan tak segan-segan membunuh. Dalam hal lain, mereka pula kerap dicitrakan suka menipu, kotor, miskin, dan bodoh. Menurut Muthmainnah (1998) satu-satunya citra positif tentang orang Madura: mereka penganut fanatik Islam yang sebagian besar warga Nahdliyin.

Stereotipdiatastidaksepenuhnya benar dan tidak seluruhnya salah. Pandangan seperti itu lahir karena minimnya informasi tentang Madura. Pulau di sisi utara Jawa Timur itu memang menyimpan banyak cerita, bukan saja ketandusannya, tapi juga orang-orangnya yang unik dan menggelitik (Jumadi, 2016). Inilah wilayah yang oleh antropolog Clifford Geertz, dikategorikan sebagai "Indonesia luar", sedangkan pulau Jawa sebagai "Indonesia dalam". Keduanya oleh Kuntowijoyo (2002) dibedakan dari sudut ekologi, di mana Madura sebagai masyarakat dengan ekologi tegal, adapun Jawa sebagai masyarakat dengan ekologi sawah.

Dilihat dari perspektif ekologis, sistem pertanian tegalan dengan tanah yang tandus dan curah hujan yang sangat terbatas mengondisikan para petani Madura menghasilkan pertanian yang serba terbatas (Jafar 2017). Kondisi ini secara langsung juga menciptakan kondisi kemelaratan dan kemiskinan di kalangan warga desa. Pertanian yang tidak menghasilkan produktivitas yang tinggi ini tidak sebanding dengan peningkatan jumlah penduduk yang mengalami peningkatan dari tahun ke tahun. Kondisi demikian, dalam mengatasi perbaikan nasib, pilihan untuk merantau ke luar Madura menjadi solusi yang dianggap strategis bagi orang Madura (Rozaki, 2004).

Dalam kehidupan asal orangorang Madura, di mana desa-desa tidak mempunyai batas kewilayahan melainkan suatu percampuran unit-unit kecil atau dusun-dusun yang masing-masing dibentuk dari beberapa keluarga, itulah juga yang dibawa ke daerah-daerah perantau mereka. Pola sosialisasi orang Madura memilih menciptakan individu yang percaya pada diri sendiri dari pada individu komunal dan kooperatif. Meskipun mereka telah hidup bertahun-tahun di wilayah dengan 
ekotipe sawah, misalnya, namun tetap memiliki karakteristik tersendiri sebagaimana dibentuk oleh ekotipe tegalan (Kuntowijoyo, 2002).

Ekologi tegalan itulah, yang memperlihatkan sosok orang Madura dengan kesejahteraannya tersendiri yang khas dan banyak diselimuti stereotip, yang bahkan beberapa tahun terakhir mengingatkan hubungan orang-orang Madura dengan beberapa etnis lain di daerahdaerah perantauan.

Hubungan itu ditandai dengan berbagai konflik dan tindakan kekerasan yang acapkali berakhir tragis, sementara wacana bagaimana kesejahteraan dan keunikan komunitas etnis Madura tidak dipahami orang dengan nalar yang memadai. Konflik orang-orang Madura di Sambas, di Sampit, dan di beberapa tempat di Jakarta dengan yang dikategorikan "penduduk lokal" apakah Dayak, Batak, Betawi, Sunda, Jawa atau etnis apa pun, sebagaimana lazimnya hanya mengukuhkan stereotip yang merugikan orang-orang Madura. Tidak banyak ahli yang mencoba mengkaji anatomi konflik yang melibatkan etnis Madura di berbagai wilayah itu melalui pemahaman yang steril dari stereotip di atas.

\footnotetext{
Ekotipe tegal sesungguhnya telah mewarnai karakteristik masyarakat Madura, bukan saja mereka yang tinggal di pulau Madura, tapi juga mereka yang merantau dan hidup di pulau-pulau lain, seperti di Kalimantan, Sulawesi, atau Jawa. Kenyataan menunjukkan bagaimana suatu masyarakat yang dibentuk oleh lingkungan alam kemiskinan ekologis, dapat melahirkan karakteristik sosial yang unik bahkan ketika kemiskinan ekologis itu direduksi. Bagaimana pun perubahan ekologi itu tidak serta merta mengubah pola hubungan
}

sosial (Taufiqurrahman, 2012).

Faktor lain yang menjadikan pola hubungan sosial Madura tidak mudah berubah, yaitu faktor budaya yang terbentuk oleh ekologi fisik selama berabad-abad. Seperti misalnya mobilitas geografis yang sudah terjadi sejak abad ke-19 dengan banyaknya orang Madura yang bermukim di Jawa Timur juga tidak mengubah budaya mereka. Dalam penelitiannya, Kuntowijoyo (2002) mengatakan, “Orang Madura dapat meninggalkan pulau Madura, tetapi tidak dapat meninggalkan ke-Madura-annya".

Tidak dapat meninggalkan "keMadura-annya", sejatinya dipahami dalam koridor makna betapa proses penanda ekotipe tegalan itu tetap dipertahankan dengan karakteristik yang nyaris tidak mengalami adaptasi dengan kebudayaan lokal, apakah dalam hal perilaku, etika kerja, struktur sosial, sampai pada bentuk permukiman.

Dengan memperbincangkan etnis Madura sesungguhnya tidak dapat dilepaskan dari karakteristik kulturalnya yang sangat berbeda atau bahkan bertentangan dengan karakteristik kultural masyarakat etnis lain. Namun dalam kasus kekerasan, sayangnya, masyarakat luar hanya mengidentikkan Madura dengan dua hal: carok dan celurit, sebagai simbol watak orang Madura yang kasar dan keras (Susanto, 2012).

Carok adalah suatu bentuk kekerasan yang memiliki latar dan pesan kultural, yang maknanya dapat terungkap bila carok dilihat dari konteks lingkungan sosial-budaya masyarakat Madura. Dari penelitian Wiyata disimpulkan bahwa carok selalu berawal dari konflik yang melibatkan unsur pelecehan harga diri (Wiyata, 2002). 
Huub de Jonge dalam salah satu bukunya (1995), sebagaimana dikutip Wiyata, bahwa carok muncul karena masyarakat Madura merasa tidak menemukan solusi atas konflik sosial yang dihadapinya, sehingga harus diselesaikan sendiri dengan cara kekerasan (Wiyata, 2002). Gaung "carok" telah sedemikian memasyarakat, akan tetapi nampak hanya sedikit orang yang memahami hakikat carok dan bentuk-bentuk tindakan kekerasan lainnya yang melibatkan etnis Madura selama ini, terutama di luar pulau Madura.

Selain dikenal sebagai suku pendatang yang identik dengan dunia carok, di luar Madura, mereka juga sering menunjukkan perilaku kekerasan dan tindak kriminal lainnya seperti pemerasan, penipuan, pencurian, perebutan lahan pekerjaan, mabuk-mabukan, berjudi, suka membawa senjata tajam, dan sebagainya. Mereka akhirnya mendapat stigma negatif dari masyarakat luar.

Pertanyaannya, sejauhmana agama sebagai sistem budaya berperan sebagai alat kontrol sosial di satu pihak, serta bagaimana makna kekerasan yang mereka lakukan di pihak lain? Kedua variabel di atas sangat penting ditelusuri. Selain itu, hal yang tak kalah penting adalah menganalisa sejauh mana karakter budaya dan lingkungan ikut andil memicu terjadinya berbagai bentuk perilaku dan tindak kekerasan tersebut.

Atas dasar itulah penelitian ini menggunakan teori fakta sosial Emile Durkheim untuk membaca sistem sosial keberagamaan masyarakat Madura di Semampir. Ciri yang paling utama dari fakta sosial adalah eksternal, atau berada di luar individu. Ia tercipta ketika

HARMONI Januari - Juni 2020 manusia saling berinteraksi. Untuk melihatnya pun, tidak bisa dengan hanya melihat individu per individu. Ia berada di luar individu, namun ia adalah sesuatu yang nyata. Durkheim menyebut bahwa fakta sosial adalah "sesuatu" yang riil.

Potret masyarakat Madura sebagai masyarakat dengan keberagamaan yang kuat tapi sekaligus nyaris lekat dengan budaya yang tidak selamanya mencerminkan nilai-nilai Islam, ini mengisyaratkan tentang kompleksitas kehidupan mereka yang penuh dengan tarikmenarik antar berbagai kekuatan, dari agama, ekonomi, pendidikan, sampai budaya dan politik.

Penelitian ini merupakan suatu ikhtiaruntukmelanjutkan penelusuran mengenai kasus kekerasan, baik secara fisik maupun psikis, yang melibatkan etnis Madura perantauan, khususnya di Semampir, salah satu kecamatan di Surabaya Utara. Dalam konteks ini, hendak diungkap makna dan konteks kekerasan yang dilakukan etnis Madura di daerah tersebut kaitannya dengan sosial budaya ke-Madura-an. Selain itu, penting kiranya pula untuk menjelaskan sejauh mana agama berperan sebagai alat kontrol sosial.

\section{METODE}

Penelitian ini menggunakan metode penelitian kualitatif dalam bentuk studi kasus. Subyek penelitian adalah orangorang Madura di Kecamatan Semampir, Surabaya Utara. Dipilihnya Semampir dalam kasus ini karena mayoritas penduduknya adalah masyarakat Madura yang memiliki identitas keberagamaan (keislaman) yang kuat. Namun demikian, Semampir juga begitu lekat dengan label sebagai wilayah yang akrab dengan kriminalitas seperti kasus pembunuhan, perjudian, pencurian, dan kebiasaan 
membawa senjata tajam. Kasus-kasus tersebut menjadikan Semampir dicap sebagai kawasan yang akrab dengan tindak kekerasan.

Pengumpulan data yang digunakan dalam penelitian adalah wawancara mendalam (in-dept interview) dengan berbagai informan, penelusuran dokumen, dan life story. Selain itu penelitian ini menggunakan analisis dan penafsiran terhadap fakta yang ditemukan di lapangan berdasarkan frame teori fakta sosial (Durkheim, et al. 1938). Penelitian dilakukan di Kecamatan Semampir yang meliputi kawasan Pegirian, Karang Tembok, Kampung Seng, Binteng, Sidotopo, dan sekitarnya.

\section{PEMBAHASAN}

\section{Etnis Madura di Semampir}

Menurut catatan sejarah, perpindahan orang Madura ke luar pulau Madura terkesan cukup natural. Untuk mempertahankan hidupnya orang Madura memang tidak segan-segan melakukan migrasi ke tempat lain. Hal ini tidak saja mereka lakukan pada saat kini di mana transportasi sedemikian majunya, akan tetapi sejak zaman kerajaan dan penjajahan Belanda mereka telah melakukannya, terutama sebagai reaksi penindasan penguasa pada masa itu (Mahasin, 1996)

Sayangnya, tidak diketahui secara pasti, kapan awal orang Madura mulai berpindah ke Kecamatan Semampir, Surabaya Utara. Pihak pemerintah tidak pernah secara khusus mengidentifikasi awal datangnya orang Madura (wawancara dengan salah satu pegawai kecamatan, Juni 2018). Bagian kependudukan juga tidak menyediakan rekapitulasi jumlah penduduk Semampir berdasarkan suatu etnis tertentu, dan hal ini menyulitkan peneliti untuk mengetahui data statistik jumlah suku
Madura di Kecamatan Semampir. Akan tetapi keberadaan mereka yang tersebar di daerah Semampir nampak mayoritas, selain juga ada suku Jawa, Arab, dan Tionghoa.

Umumnya orang Madura di Kecamatan Semampir bekerja di sektor nonformal seperti sopir, buruh pabrik, penjual di pasar, kuli bongkar muat di pelabuhan, tukang becak, tukang parkir, selain juga di antara mereka ada yang menjadi tokoh agama yang cukup disegani. Keberadaan masyarakat Madura di Kecamatan Semampir tersebut membentuk ciri budaya dan perilaku khas ke-Madura-an.

Tiap tahunnya jumlah suku Madura di Kecamatan Semampir terus meningkat yang pada gilirannya telah menimbulkan banyak masalah cukup kompleks dalam hal pergaulan sesama mereka maupun dengan masyarakat suku lain. Dalam banyak kasus, orang Madura sering terlibat dalam tindakan-tindakan kriminal sehingga tidak aneh bila masyarakat luar mencap mereka sebagai pembuat onar, tukang carok, penipu, dan penjudi.

\section{Karakter Orang Madura di Semampir}

Persepsi orang luar Madura terhadap orang Madura, khususnya di Kecamatan Semampir, selama ini nampak terlalu simpel. Orang Madura hanya dilihat sebagai entitas etnis tunggal dengan stereotip yang cenderung naïf. Stereotip negatif ini yang membuat kalangan menengah Madura di Semampir kadang sulit mengakui manakala mereka ditanya orang dari suku lain. Sebab, masyarakat suku lain telah punya persepsi yang kurang bagus tentang orang Madura di Semampir.

Gambaran orang Madura di Semampir pada hakikatnya tidak jauh 
berbeda dengan stereotip tentang orang Madura di manapun berada. Mengutip Huub de Jonge (1995), stereotip tersebut sebetulnya sudah ada sejak zaman kolonial Belanda, namun masih hidup dan relevan hingga saat ini. Dalam kacamata orang Jawa, misalnya, orang Madura diilustrasikan secara fisik lebih jelek dibandingkan orang Jawa. Raut muka orang Madura berbentuk lebar dan tidak mencerminkan sinar kelembutan. Sifat mereka kolot dan mempunyai tulang pipi yang agak cembung dengan bentuk wajah yang sedikit angker.

Rumah-rumah orang Madura di Semampir terlihat semrawut dan kotor. Tidak saja dari segi lahiriyah, watak orang-orangnya seringkali menampilkan sikap kasar dan sangar. Sifat mereka yang temperamental dan suka berbicara dengan nada tinggi turut pula memperkuat stereotip di atas (Wawancara dengan Pak Samin dan Bu Tutik, keduanya warga Semampir asal Jombang dan Solo, Agustus 2018).

Masyarakat Madura di Semampir dalam benak suku lain tidak lebih dari kebodohan, kekotoran, celurit, dan kekerasan. Di bidang ekonomi, orang Madura di Semampir akrab dengan penjual sate, penarik becak, tukang cukur, atau pedagang besi tua. Pada sisi lain, mereka memang dipandang sebagai orang yang taat beragama dan patuh pada kiai. Selain itu, mereka juga dikenal sebagai pekerja keras, khususnya di sektor yang mengandalkan tenaga fisik.

Potret etnis Madura sebagai masyarakat dengan keberagamaan yang kuat, tetapi sekaligus nyaris lekat dengan budaya yang tidak selamanya mencerminkan nilai-nilai Islam. Hal ini mengisyarakatkan tentang kompleksitass kehidupan mereka yang penuh dengan tarik-menarik antara berbagai kekuatan, dari sisi agama, ekonomi, pendidikan sampai budaya.

\section{Kondisi Sosial Budaya Etnis Madura di} Semampir

Ilustrasi tentang kehidupan sosial budaya masyarakatMadura diSemampirsebagaimana ditemui dalam gambaran orang Madura di mana pun beradapada dasarnya terdapat paling tidak tiga citra diri (self-esteem), yaitu kesopanan, kehormatan dan Islam (Junaidy, 1999). Pada subjudul ini peneliti mengurai ciri kesopanan dan kehormatan, sementara ciri keagamaan (Islam) akan dibahas pada subjudul berikutnya.

\section{Kesopanan}

Salah satu tradisi yang amat penting bagi masyarakat Madura di Semampir adalah kesopanan yang harus dijunjung tinggi. Kendati orang luar suku Madura menilai mereka sangat kasar, namun penghormatan terhadap nilai-nilai kesopanan sangat tinggi sekali.

Betapa pentingnya nilai kesopanan ini nampak dari ungkapan $t a^{\prime}$ tao batona langgar (tidak pernah merasakan lantainya langgar). Maksudnya, orang tersebut belum pernah masuk langgar dan mengaji atau belum pernah mondok di pesantren, sehingga tidak tahu tata krama kesopanan. Ungkapan ini untuk orang yang tidak tahu atau melanggar nilai-nilai kesopnan.

Ungkapan lain yang memberikan nasihat dan ajaran tentang keharusan bersopan santun adalah $p a$ tao jalana jalana, pa tao neng neng, pa tao a ca ca (yang menjadi kewajiban harus dilaksanakan sesuai dengan aturan, harus tahu saatnya diam, harus tahu saatnya berbicara). Hal ini bermakna bahwa orang Madura di Semampir harus selalu tahu aturan, nilai dan tata karma dalam setiap tindakannya.

Selain itu, setiap kewajiban harus dilaksanakan dengan mendasarkan pada aturan-aturan tata karma yang ada. Orang dan masyarakat Madura di Semampir selalu menekankan bahwa mon oreng reya 
banne bagusse tape tatakramana, sanajjan bagus tape tatakramana juba', ma' cellep ka ate (yang penting bukan ketampanan atau kecantikan namun tatakramanya, meskipun bagus atau cantik kalau tatakramanya jelek, dapat membuat hati menjadi tidak enak).

Dasar utama dari nilai-nilai kesopanan adalah penghormatan orang Madura kepada orang lain, terutama yang lebih tua atau dari kalangan strata sosial yang lebih tinggi. Nilai-nilai kesopanan ini mengatur hubungan antargenerasi, kelamin, pangkat, dan stratifikasi sosial.

\section{Warga Madura di Semampir} intinya menuntut adanya kesopanan dalam segala tindakan sehari-hari, termasuk dalam hal berbahasa. Mereka kadang terlihat berbicara dengan bahasa halus kepada orang lain terutama ketika berkomunikasi dengan orang yang baru dikenal. Namun ironisnya, mereka lebih sering tidak konsisten dalam mengaplikasikan bahasa halus, terutama ketika terlibat dalam suatu konflik.

\section{Kehormatan}

Sebagaimana telah disebutkan di atas, orang Madura di Semampir sangat mengutamakan penghormatan dan penghargaan, apalagi kepada yang lebih tua atau yang mempunyai kedudukan sosial yang lebih tinggi, sehingga menjadikan nilai-nilai kesopanan menjadi sangat penting sekali dalam kehidupan bermasyarakat.

Komunitas Madura di Semampir juga tidak mau diremehkan. Namun demikian, penonjolan diri pun tidak dihargai. Sifat yang demikian termanifestasikan dalam ungkapan madu dan dara (madu dan darah), yang berarti siapa pun orang Madurabila diperlakukan dengan baik, dijunjung tinggi nilai-nilai kesopanan dan penghormatan, maka ganjarannya adalah kebaikan pula. Sebaliknya, bila ia diperlakukan secara sewenang-wenang dan tidak adil, maka balasannya jauh lebih berat bahkan dapat menimbulkan pertumpahan darah.

\section{Perilaku Ekonomi Orang Madura di Semampir}

Kebanyakan orang Madura yang bermigrasi ke tanah Jawa tidak mempunyai keterampilan khusus untuk bersaing dalam gaya hidup perkotaan, dan karenanya mereka kemudian terjun ke dunia jasa atau informal yang tidak memerlukan persyaratan-persyaratan tertentu. Sejarah hidup mereka di Pulau Madura yang pernah mengalami berbagai tekanan dari penguasa pada zaman kerajaan dan penjajahan serta kondisi alamnya yang serba terbatas, telah membentuk jiwa mereka untuk selalu memanfaatkan setiap peluang yang mengandung nilai ekonomis (Faraby and Faiza 2014).

Begitu pula sosok orang Madura di Semampir-sebagaimana umumnya orang Madura di beberapa tempat perantauandikenal sebagai penarik becak, penjual sate dan soto, tukang potong rambut tradisinal atau penjual barang-barang bekas, selain juga sebagai pedagang sayuran, buah-buahan dan ikan di pasar.

Sebagai pedagang, orang Madura di Semampir dipandang cukup ulet. Mereka adalah pekerja keras yang tersebar di pasar sekitar Semampir. Para orang tua Madura di sana lebih banyak mengarahkan anak mereka untuk menekuni dunia kerja. Sehingga, kebanyakan dari mereka cenderung membuka usaha sendiri ketimbang, misalnya, melanjutkan pendidikan ke jenjang yang lebih tinggi. Mereka lebih suka membuka warung sendiri atau menggeluti usaha barang bekas daripada menjadi buruh pabrik. 
Tidak jarang di antara mereka yang mendulang suskses besar dalam berdagang atau berbisnis. Sekalipun mayoritas dari mereka tidak mengenyam pendidikan formal atau maksimal hanya berpendidikan SLTP, mampu membaca peluang yang ada. Sebagai contoh, dulu orang mungkin tidak mengira kalau barang bekas mempunyai nilai ekonomi, tetapi sekarang ternyata barang tersebut bisa mendatangkan keuntungan besar. Kunci sukses lainnya, mereka memiliki jiwa totalitas tanpa batas sebagai prinsip utama dalam bekerja.

Semangat berwiraswasta seakan sudah melekat dan menjadi budaya bagi sebagian masyarakat Madura di Semampir. Hidup di perantauan telah memacu semangat kreativitas dan kemandirian mereka. Sehingga tidak mengherankan, di antara mereka benarbenar merintis usaha dari bawah sampai menjadi wiraswasta yang berhasil.

Namun permasalahannyalazimnya gambaran tentang orangorang Madura di dalam maupun di luar pulau Madura-mereka cenderung mengabaikan pendidikan formal. Akibatnya, tidak jarang bisnis yang mereka geluti tidak terkelola dengan baik, sehingga dalam kompetisi bisnis mereka lebih sering mengandalkan emosi.

Selain unsur emosional yang sering mewarnai karakter orang Madura di Semampir, juga iklim kemiskinan mayoritas masyarakatnya terkadang turut menyumbang terjadinya kekerasan atauminimal-suasana kesemrawutan. Lebihlebih bila dibandingkan dengan kondisi ekonomi etnis Tionghoa yang berada di Kecamatan Semampir, mayoritas dari masyarakat Madura masih jauh dari kemapanan.

Dalam pengamatan peneliti, banyak dijumpai rumah-rumah orang Madura di
Semampir berukuran kecil, kumuh, dan saling berdempetan antara satu rumah dengan lainnya, yang dihuni sekian banyak anggota keluarga dan anak-anak yang tak terurus/terdidik dengan baik. Dalam beberapa kasus kekerasan yang dilakukan orang Madura di Semampir kebanyakan memang karena faktor ekonomi. Demi mendapatkan uang, misalnya di antara mereka kadang menempuhnya dengan jalan pintas seperti berjudi lewat sabung ayam dan main togel, mencuri atau dengan cara menipu dan memeras orang lain.

\section{Kehidupan Keberagamaan Warga Madura di Semampir}

Pembicaraan tentang agama bagi masyarakat Madura umumnya dan bagi orang Madura di Semampir khususnya, selalu diidentik dengan Islam (Syamsuddin 2018). Islam merupakan hal suci yang harus dibela dan dipertahankan. Maka orang Madura tidak akan sungkansungkan untuk mempertaruhkan nyawanya bila merasa agamanya dihina (Faraby, 2016).

Betapa pentingnya nilai-nilai agama terungkap dari ajaran abantal syahadat, asapo' angin, apajung Allah. Artinya masyarakat Madura sangat religius. Begitu pula masyarakat Madura di Semampir tergolong pemeluk agama Islam yang taat. Demikian lekatnya Islam pada masyarakat Madura di Semampir, sehingga akan terdengar aneh jika ada yang tidak beragama Islam.

Warga Madura di Semampir begitu rajin menjalankan ritual keagamaan dalam kehidupan privat maupun publik. Kehidupan keberagamaan mereka berakar kuat dalam adat orang-orang Madura terdahulu sebagaimana peneliti saksikan. Di Semampir sepanjang tahun penuh diisi dengan selamatan-selamatan Islam. Dalam kehidupan sehari-hari, masyarakat Madura bisa dikatakan sudah 
"menyatu" dengan upacara-upacara keagamaan mulai dari acara kelahiran, perkawinan, dan kematian.

Melaksanakan rukun Islam kelima, yakni ibadah haji merupakan cita-cita tertinggi orang Madura di Semampir. Ini tampak dari kalangan mereka yang gigih menabung dengan bekerja keras (Wawancara dengan Pak Masruh, seorang kuli bangunan dan Bu Sum, pemilik warung sate kambing di depan pasar Pegirian, 15 Juni 2018). Kebiasaan menabung orang Madura di Semampir tidak saja dalam bentuk uang, akan tetapi juga dalam bentuk perhiasan emas yang akan mereka gunakan untuk berangkat haji ke tanah suci.

Maka biasanya, ketika orang Madura di Semampir ditanya tentang tujuan mereka menabung, kebanyakan dari mereka lebih memprioritaskan niat untuk ongkos haji ketimbang, misalnya, untuk kebutuhan biaya pendidikan anak-anaknya. Tidak aneh jika banyak dijumpai dari kalangan anak-anak atau remaja Madura di Semampir terbengkalai pendidikannya, sekalipun orangtua mereka sebetulnya cukup mampu dari segi finansial.

Adapun simbol keagamaan mereka yang paling menonjol adalah sosok kiai. Itulah yang menyebabkan lapisan atas (elite) pada stratifikasi sosial masyarakat Madura di Semampir-dilihat dari dimensi keagamaan-ditempati oleh para kiai. Mereka bukan hanya sebagai pemuka agama, namun juga sebagai pemimpin masyarakat. Para kiai dipandang memiliki kendali legitimasi dan otoritas kharismatik, sehingga buah pikirannya mudah sekali diterima.

Terutama golongan tuanya dari Semampir yang dibesarkan di pulau Madura dan pernah mendapatkan sentuhan kiai di pondok pesantren tradisional. Itu sebabnya mereka tidak bisa dipisahkan dengan kewajiban-kewajiban ritual dalam keseharian. Sosok kiai sangat dominan dalam kehidupan mereka. Kepemimpinan formal pun tidak mampu mengalahkan dominasi kepemimpinan para kiai. Bagi mereka, tugas-tugas dari pemerintah, lebih terkesan menjadi beban ketimbang dilakukan secara suka rela.

Pamor seorang kiai begitu bersinar di tengah-tengah kehidupan masyarakat Madura di Semampir. Mereka sangat patuh kepada sosok kiai karena dianggap memiliki kekuatan spiritual yang menonjol. Kepada kiai inilah, warga Madura di Semampir mengadukan nasib dan masalah keseharian mereka. Secara tidak langsung, kiai menjaga tradisi dan nilai-nilai hidup masyarakatnya dari kalangan etnis Madura. Tidak berlebihan, jika dikatakan, kiai paling tahu apa yang dibutuhkan warga Madura di Semampir.

Bukan dalam bidang keagamaan saja, melainkan juga dalam kegiatan sosial, bahkan juga politik. Harapan yang diberikan masyarakat kepada kiai sangat besar sekali. Ia dianggap sebagai personifikasi yang luas pengetahuannya tentang agama Islam, pembangkit inspirasi, dan aspirasi, pembentuk kebijakan yang arif, bahkan dituntut kesanggupannya menjadi politikus yang cerdik (Sasongko and Wahyuni, 2013).

Dampak harapan yang berlebihan terhadap kiai tersebut, menimbulkan fenomena di kalangan kiai, di Semampirmeski tidak secara keseluruhan-yang meletakkan politik hampir setara dengan "agama". Tak jarang, agama terkesan sebagaialatkepentingan politik pragmatis. Agama juga dijadikan alat kampanye untuk meraih kekuasaan dan sejenisnya, terutama detik-detik menjelang pemilu yang biasanya dibungkus melalui acara pengajian. Di hadapan jamaahnya, seorang kiai kemudian menanamkan rasa kebencian kepada kelompok-kelompok tertentu, yang tidak jarang menimbulkan tindak kekerasan di kalangan masyarakat biasa. Bentuk kekerasan yang dilakukan

\begin{tabular}{l|l} 
Jurnal Multikultural \& Multireligius Vol. 19 & No. 1
\end{tabular} 
biasanya dengan cara menurunkan bendera Parpol tertentu atau meneror anggotanya (Dialog dilakukan dengan Pak Said, sesepuh warga Madura di Semampir, 16 Juli 2018).

Politisasi agama itu kemudian dipenuhisimbol-simboldanbingkaidalam makna baru untuk mengartikulasikan klaim-klaim yang bersifat sosio-politik, ekonomi, dan budaya. Politik yang telah menjadi "agama baru" itu membuat sebagian kiai sangat pragmatis untuk meraih keuntungan keduniawian seperti misalnya, penggunaan simbol-simbol agama sebagai captivation (pemikat hati) untuk melanggengkan kekuasaan dan pengaruh mereka di mata masyarakat.

Persoalan kian menjadi rumit, ketika sebagian orang yang dianggap sebagai tokoh agama (kiai) terlibat dalam pelestarian corak keberagamaan yang menjurus ke arah perilaku kekerasan. Seperti misalnya, ada sebagian kiai yang bersedia melakukan proses "pengisian" mantra-mantra atau jampi-jampi ke tubuh calon pelaku kekerasan, selain juga kadang sebagai guru ilmu kanuragan (kekebalan). Dalam perkembangannya, kiai Madura di Semampir menguasai banyak wilayah sosial di masyarakat, yang secara ekonomi dan politik sangat menguntungkan.

\section{Beberapa Kasus Kekerasan dan Motifnya}

Berdasarkan informasi yang didapat dari Polsekta Semampir (16 September 2018), dalam beberapa kasus kekerasan yang ditangani Polsekta Semampir, hampir 90\% pelakunya adalah etnis Madura. Selama 9 bulan, (Januari-September 2018) tercatat kasus pembunuhan (1 kali), perjudian (17 kali), pencurian (14 kali), dan membawa senjata tajam (5 kali). Selebihnya juga terjadi kasus penipuan (6 kali), pemerasan (4 kali), mabuk-mabukan, dan penjualan CD pornografi.
Dalam studi ini hanya mengambil empat kasus pertama serta berusaha mendeskripsikan beberapa faktor yang mendukungnya.

\section{Pembunuhan}

Pada suatu hari, sekitar pukul 19.00 WIB, bulan Januari 2003, peristiwa pembunuhan terjadi di terminal Binteng, ketika Subaidi (49 th) mencelurit Mukimin (43 th). Keduanya adalah warga Madura Semampir, tapi berbeda kampung. Dengan cara nyelep (menikam dari belakang) Subaidi membacok Mukimin. Akibat perbuatannya, Subaidi dipidana dengan hukuman penjara selama lima tahun, dipotong masa tahanan sementara selama tiga bulan. Subaidi didakwa melanggar pasal 340 KUHP, karena terbukti melakukan pembunuhan yang telah direncanakan sebelumnya (Dialog dengan Kasat Reskrim Polsekta Semampir, Juli 2018).

Sebagaimana dituturkan aparat kepolisian, latar belakang pembunuhan di atas adalah karena ada motif perselingkuhan antara Saidah (istri Subaidi) dengan Mukimin. Menurut keterangan beberapa informan, khususnya para tetangga Subaidi, pada mulanya Subaidi hanya mendengar desas-desus bahwa istrinya yang seharihari membuka warung nasi di terminal Binteng, menjalin hubungan cinta dengan Mukimin, seorang sopir angkutan umum. Gosip itu semakin hari semakin santer. Hati Subaidi bertambah panas ketika mendengar bahwa mereka sudah sampai ke tingkat perbuatan zina. Bagi Subaidi yang kesehariannya hanya kuli serabutan itu, tindakan Mukimin dianggapnya sebagai pelecehan terhadap harga diri dan keluarganya.

Sejak saat itu, Subaidi berniat untuk membunuh Mukimin dengan cara nyelep (menikam diam-diam dari belakang). Cara ini dilakukan, sebab 
Mukimin dikenal memiliki ilmu bela diri, selain postur tubuhnya yang tinggi besar, sementara tubuh Subaidi bisa dibilang kurus kering. Maka bagi Subaidi tidak ada cara lain untuk membunuh Mukimin kecuali dengan cara menikamnya dari belakang.

Akhirnya dengan membawa sebilah celurit, Subaidi pada malam hari, sekitar pukul 19.30 WIB secara diam-diam berangkat menuju warung istrinya (kirakira $1 \mathrm{~km}$ dari arah pasar Binteng) yang memang selama ini selalu ramai dengan sopir-sopir angkutan umum. Kebetulan malam itu juga ada Mukimin yang sedang berbincang-bincang dengan istrinya.

Sebelum pembunuhan itu dilakukan, sengaja Subaidi menunggu saat yang tepat untuk membabat tubuh korbannya dari sudut tempat yang agak tersembunyi. Setelah merasa pas waktunya, ia segera keluar dari persembunyiannya dan langsung melancarkan beberapa bacokan ke tubuh Mukimin di bagian belakang. Tanpa ada perlawanan sama sekali, Mukimin tersungkur ke tanah dan tewas seketika.

Beberapa tahun sebelum kegiatan penelitian lapangan ini dilakukan, juga telah terjadi peristiwa carok di Kampung Seng dengan motif balas dendam. Kejadian itu sebetulnya bermula dari peristiwa 15 tahun silam. Menurut Mat Hari (Maret, 2018), salah seorang warga Kampung Seng yang menyaksikan kejadian tersebut, menceritakan bahwa Bunawi adalah seorang pembunuh, yang merantau ke Jakarta karena takut terhadap pembalasan keluarga korban. Lima belas tahun kemudian, Bunawi mengira keluarga korban sudah melupakannya, ia akhirnya pulang kampung karena rindu kepada keluarganya. Tetapi dendam itu tidak surut, ketika ia sampai ke kampungnya itulah, babatan celurit anak korban menyambut kedatangan Bunawi di depan rumahnya. Dendam keluarga korban yang telah tertidur selama 15 tahun, tiba-tiba bangkit menagih janjinya. Dan hampir menjadi semacam perintah dalam tradisi suku (berdarah) Madura: dendam carok harus dibalas dengan carok.

\section{Perjudian}

Seiring dengan kondisi kemiskinan dan lemahnya norma-norma sosial di Semampir, telah mengakibatkan suburnya lahan-lahan perjudian di beberapa sudut tempat. Agama yang sejatinya dapat berperan dalam menjaga prilaku sosial, hampir tidak terbukti di Semampir. Bahkan tidak ada sosok kiai yang mau terjun langsung untuk mengatasi praktik perjudian.

Sementara sekian pengajian yang disampaikan para kiai di masjidmasjid, khususnya di Masjid Bujuk Lanceng dan beberapa Masjid di bawah kepenguruan orang-orang Madura, hanya menyinggung masalah-masalah problem masyarakat yang mendasar. Apalagi khutbah-khutbah yang mereka perdengarkan setiap Jum'at-sepanjang sepengetahuan peneliti-hanya berbentuk bahasa Arab (diambil rukunrukun khutbahnya saja), tanpa diartikan ke dalam bahasa Indonesia atau bahasa Madura. Bias dipastikan, hampir semua para jamaah tidak memahami isi khutbah yang telah disampaikan khatib.

Terkadang banyak juga di antara jamaah salat Jum'at tersebut, tidak seratus persen melaksanakan salat lima waktu tiap harinya atau melakukan salat wajib tapi masih banyak bolongnya, dan bahkan sebagian dari mereka adalah pelaku perjudian. Hal ini menunjukkan bahwa sebagian dari mereka melakukan salat Jum'at atau ibadah-ibadah wajib yang lain (seperti kasus ibadah haji di atas), lebih dipandang sebatas seremonial belaka, ketimbang sebagai ibadah ritual yang sakral. Akibatnya, banyak ibadahibadah yang secara formal telah mereka 
lakukan, tetapi tidak berimplikasi sikap sosial. Di antaranya, kasus perjudian masih terus terpelihara di tengah-tengah masyarakat.

Ada banyak jenis perjudian yang terlihat di kalangan masyarakat Madura di Semampir, dan yang paling mencolok di beberapa tempat adalah adu merpati, sabung ayam, dan tombokan togel (toto gelap). Adu merpati biasanya menempati arena yang cukup luas seperti di sebuah lapangan. Berjudi lewat adu merpati tidak saja dimonopoli oleh mereka yang mempunyai burung merpati, tapi ada juga beberapa orang yang datang hanya untuk taruhan. Adu merpati dilakukan hampir setiap hari, pada waktu sore sampai menjelang maghrib, yang ratarata diikuti oleh kaum laki-laki.

Adapun judi sabung ayam biasanya dilakukan oleh sekelompok orang dengan mengambil lokasi di depan pekarangan rumah yang agak luas. Uang yang dipertaruhkan dalam perjuadian sabung ayam cenderung lebih besar dari pada taruhan dengan adu merpati. Waktunya juga tidak dilakukan setiap hari, tapi tergantung kesepakatan beberapa calon peserta taruhan. Seminggu kadang berlangsung hanya sekali saja.

Sebetulnya, beberapa arena perjudian sabung ayam maupun adu merpati tidak begitu jauh dari kantor kepolisian. Ada yang hanya berjarak $3 \mathrm{~km}$ sampai $5 \mathrm{~km}$. namun, kata Tohir (dituturkan pada Maret 20018), seorang warga Madura yang tinggal di Karang Tembok, beberapa tempat perjudian di Kecamatan Semampir dibekingi oleh sebagian oknum polisi. Maka, tidak heran jika ada beberapa tempat perjudian yang ada di Semampir terpelihara dengan rapi.

Bentuk judi lainnya yang sangat popular di kalangan masyarakat Madura di Semampir (mungkin juga di seluruh
Indonesia) adalah togel. Togel sebenarnya bukan jenis perjudian baru. Sebelumnya juga ada jenis perjudian serupa togel, yaitu PORKAS dan SDSB. Simpatisan togel di Semampir umumnya terdiri dari masyarakat Madura kelas menengah ke bawah, tidak hanya kaum lelaki saja, melainkan di antara mereka ada juga perempuan. Suatu hari, peneliti pernah melihat sendiri seorang perempuan (tepatnya seorang nenek) menitipkan tombokan togel kepada salah seorang tetangganya. Padahal, seorang nenek itu juga melakukan salat, puasa, dan ibadah wajib lainnya. Memang dari segi ekonomi, seorang nenek tadi tergolong miskin.

\section{Pencurian}

Sebagai rentetan dari akibat perjudian, salah satunya adalah perilaku pencurian. Tidak berlebihan kiranya, jika peristiwa yang terjadi di beberapa tempat di Kecamatan Semampir merupakan hukum kausalitas dari maraknya perjudian. Empat belas kali kasus pencurian yang tercatat di kantor kepolisian sektor Semampir, dalam rentang waktu 9 bulan, merupakan angka yang cukup tinggi.

Peristiwa pencurian yang terjadi, kebanyakan dilakukan pada malam hari, mulai dari pencurian uang, televisi, sampai sepeda motor. Menurut data kepolisian Semampir, yang berhasil mengorek keterangan dari para pencuri yang tertangkap, alasan mereka melakukan pencurian karena sebelumnya kalah judi atau ingin menggunakan hasil curiannya untuk modal berjudi, dan ada pula sebagian untuk membeli minuman keras.

Secara umum, respons masyarakat Madura di Semampir terhadap kasus perjuadian dan pencurian sangat negatif. Selain bertentangan dengan ajaran agama 
Islam, kedua kasus tersebut selama ini sangat mengganggu ketenangan mereka. Sebab cepat maupun lambat, tradisi perjudian dan pencurian akan selalu mengancam hak milik mereka atau setidaknya mencemarkan identitas etnis Madura di Semampir.

\section{Kebiasaan Membawa Senjata Tajam}

Tindakan lain yang juga cukup meresahkan masyarakat umum yaitu kebiasaan sebagian orang Madura di Semampir-meskipun dalam jumlah kecilyang masih suka nyekep (membawa senjata tajam dengan cara menyembunyikannya di balik baju). Biasanya senjata yang dipakai untuk nyekep adalah celurit atau pisau berukuran kecil dengan panjang sekitar $50 \mathrm{~cm}$ yang mudah diselipkan di balik baju, sehingga tidak mengundang perhatian orang lain, terutama aparat kepolisian.

Bagi sebagian warga Madura di Semampir, senjata tajam merupakan semacam "nyawa cadangan". Seperti dituturkan oleh Jamil (5 Juli 2018), seorang calo pembuatan paspor bagi calon TKI ke luar negeri, bahwa tidak ada jaminan keamanan selama 24 jam bagi seseorang, sementara sewaktu-waktu ada orang lain yang ingin berbuat jahat. Tanpa bermaksud meremehkan peranan polisi, Jamil mengatakan bahwa polisi tidak akan sanggup menjaga seseorang selama 24 jam, maka ia perlu nyekep untuk keselamatan jika tiba-tiba ada serangan.

Kebiasaan Jamil untuk nyekep tersebut menggambarkan kesiapan diri untuk melakukan carok jika menghadapi suatu konflik atau pertikaian yang bisa muncul setiap saat dan segala tempat. Padahal menurut undang-undang, membawa senjata tajam dianggap sebagai tindakan kejahatan yang dapat diancam kurungan penjara. Tetapi kebiasaan nyekep masih terus berlangsung bagi sebagian orang Madura di Semampir sekalipun diancam dengan hukuman penjara.

Maka ketika Polda Jatim pernah mengadakan operasi senjata tajam, sebagian dari masyarakat enis Madura di Jawa Timur justru melakukan protes dan mengeluhkannya terkait dengan penyitaan senjata tajam (Surya, 13 Mei 2013). Sangat dimaklumi bila dalam selang waktu 9 bulan, aparat kepolisian berhasil mengamankan 5 orang Madura Semampir yang ketahuan membawa senjata tajam.

Kasus-kasus kekerasan di atas yang melibatkan etnis Madura di Semampir semakin mempertegas stereotip tentang masyarakat Madura perantauan yang cenderung berlaku kasar. Termasuk salah satu karakteristik masyarakat Madura di Semampir yang dinilai kurang sopan terutama di mata orang Jawa. Orang Madura cenderung menampilkan karakter yang apa adanya. Artinya, orang Madura yang menetap di Semampir khususnya, atau yang menetap daerah manapun pada umumnya, memang memiliki sifat ekspresif, spontan, dan terbuka.

Ekspresi, spontanitas, dan keterbukaan orang Madura di Semampir, termanifestasikan ketika mereka merespons segala sesuatu yang dihadapi atas perlakuan orang lain terhadap dirinya. Misalnya, jika perlakuan itu membuat hati senang, maka secara terus terang tanpa basa-basi, mereka akan mengungkapkan rasa terima kasihnya seketika itu juga. Sebaliknya, mereka akan spontan bereaksi keras bila perlakuan terhadap dirinya dianggap tidak adil dan menyakitkan hati.

Cara orang Madura di Semampir saat merespons sakit hatinya akan berupa 
tindakan resistensi yang cenderung keras. Keputusan perlu tidaknya menggunakan kekerasan fisik dalam tindakan resistensi ini sangat tergantung pada tingkat pelecehan yang mereka rasakan. Resistensi yang paling kuat biasanya berkaitan dengan gangguan terhadap istri atau kasus perselingkuhan.

Dalam konteks ini, berarti bahwa nilai-nilai sosial budaya ke-Maduraan membuka peluang bagi ekspresi individual secara lebih transparan. Bahkan, secara sosial pun setiap individu tidak ditabukan untuk mengungkapkan perasaan, keinginan atau kehendaknya, sekalipun cara-cara yang dilakukan mengandung unsur-unsur kekerasan seperti kasus membela harga diri, atau setidaknya meresahkan orang lain seperti kebiasaan membawa senjata tajam.

Sementara dalam beberapa kasus seperti perjudian dan pencurian yang terjadi wilayah Semampir, biasanya dipicu oleh kondisi kemiskinan yang mewarnai sebagian besar penduduk Madura di sana. Mayoritas dari mereka adalah golongan oreng kene' (wong cilik) yang mencakup para sopir, buruh kasar di pasar, penarik becak, tukang bengkel, kuli musiman di pelabuhan, termasuk juga kaum pengangguran.

Selain faktor ekonomi yang serba terbatas, lingkungan sosial dengan tingkat pendidikan rendah ikut memicu terjadinya beberapa kasus kekerasan. Minimnya tingkat pendidikan diduga sebagai salah satu sebab lain mengapa orang Madura di Semampir mempunyai karakter tersendiri di tengah masyarakat suku lainnya sebagai etnis yang gampang terpancing secara emosional.

\section{Peran Agama dalam Kehidupan Masyarakat Madura di Semampir}

Sebagai sebuah fakta sosial, agama selalu mengalami perkembangan yang sangat dinamis. Agama senantiasa menghadapi tuntutan untuk melakukan social adjustment dengan realitas sosial yang melingkupinya. Sebab ketika hal ini diabaikan, maka agama hanya akan menyisakan dongeng dan mitos-mitos tentang akhirat, pahala, dosa, surga, neraka, dan sejenisnya. Padahal esensi agama adalah bagaimana sebagai sebuah entitas yang lahir dari konstruksi sosial menjadi nilai-nilai yang akrab dengan persoalan sosial.

Agama sebagai realitas sosial merupakan salah satu bagian identitas tersendiri bagi masyarakat Madura di Semampir. Namun, bagaimana identitas itu dikonstruksikan dan diekspresikan tampaknya jalan keberagamaan yang dilaluinya tidaklah tunggal (Rozaki 2004), Sebagai sebuah fakta sosial, itulah keberagamaan yang berkembang dalam masyarakat Madura di Semampir belum tentu merepresentasikan secara utuh nilainilai yang terdapat dalam agama normatif yang bersifat absolut, transendental dan universal. Pada saat yang sama malah kadang muncul pembiasan atau reduksi dari nilai dan ajaran substansial agama.

Secara prinsip, keberagamaan masyarakat Madura di Semampirsampai derajat tertentu-belum mampu mengembangkan etika-moral agama yang bersifat perennial secara maksimal. Doktrin agama yang sejatinya memiliki makna transformative, yang berkaitan erat dengan nilai-nilai kemanusiaan dan keamanan sosial belum dapat diwujudkan ke dalam satu etika-moralitas praktis yang dapat dijadikan pedoman hidup mereka.

Akibatnya, sebagianmerekaterjebak ke dalam keberagamaan legalistik yang menekankan pola pandang yang bersifat lahiriyah dan terkesan eksklusif. Mereka hanya menyikapi segala persoalan yang dihadapi dalam kerangka legal-formal yang telah terputus dari akarnya yang bersifat moral. Dalam konteks ini, agama 
lebih merupakan suatu bentuk budaya, dalam arti, agama serupa dengan budaya terdiri dari kepercayaan, nilai, norma, dan gagasan yang dialami bersama dan menciptakan identitas bersama di dalam suatu kelompok tertentu (Hidayat and Hariri, 2017).

Dalam kondisi seperti itu, agama mengalami kesulitan untuk berdialog secara transformatif dengan budaya dan tradisi yang begitu melekat dengan kehidupan mereka. Hal yang terjadi justru pembungkusan tradisi dan budaya atas nama agama tanpa ada perwujudan nilai religiusitas yang signifikan untuk mewarnai budaya tersebut. Selain itu, kearifan budaya lokal-semacam harga diri yang begitu disakralkan oleh setiap orang Madura-dibiarkan tumbuh liar sehingga mengalahkan nilai-nilai moral yang seharusnya menjadi alat pembersih dari stigma negatif yang mereka "sandang" selama ini.

Keberagamaan secara legalformalistik telah mengantarkan sebagian pemuka agama (kiai) di Semampir pada upaya membungkus agama sebagai alat kepentingan yang sarat dengan nuansa politik pragmatis. Agama dijadikan media untuk melanggengkan kekuasaan dan pengaruhnya di tengahtengah masyarakat seperti misalnya, menyulap acara pengajian agama sebagai ajang kampanye terselubung, setelah sebelumnya melakukan koalisi dengan salah satu kekuatan politik tertentu.

Memang ironis, sosok kiai yang seharusnya sebagai benteng moral masyarakat Madura di Semampir ternyata juga "teracuni" oleh imingiming politik yang menggiurkan, bahkan sebagian di antara mereka-sedikit atau banyak-mendukung perilaku yang dekat dengan nuansa kekerasan atau kehidupan yang jauh dari sentuhan nilainilai luhur agama, seperti kasus kiai yang memberikan jampi-jampi kepada seseorang yang ingin berbuat jahat.
Pada tataran ini, "agama" bukan dijadikan sebagai sumber dan ajaran moral, tapi lebih ditampakkan sebagai kekuatan yang melanggengkan pertentangan, kekerasan, dan tindakantindakan dehumanistik lainnya. Dalam konteks ini, agama sebagai sistem budaya telah mengalami "pembusukan" dari dalam agama itu sendiri sehinggasecara sosiologis-tidak bisa diandalkan sebagai satu-satunya alat kontrol sosial.

\section{SIMPULAN}

Untuk merumuskan pola pandang dari seluruh uraian di atas, kiranya perlu diambil beberapa kesimpulan sebagai berikut: pertama, perilaku kekerasan yang dilakukan orang Madura di Semampir berupa pembunuhan, perjudian, pencurian, kebiasaan membawa sejata tajam, dan sejenis tindak kekerasan lainnya, terkait erat dengan beberapa faktor. Faktor yang paling menonjol adalah sikap mengagungkan harga diri yang terlalu ekstra, sehingga kadang harus mempertahankannya dengan tebusan nyawa. Selain persoalan harga diri, faktor keterbatasan ekonomi, keterbelakangan pendidikan, dan pemahaman budaya lokal yang salah, menyebabkan sebagian suku Madura di Semampir terjebak dalam tindak kriminalitas.

Kedua, proses interaksi orang Madura di Semampir yang multietnis, memang memiliki karakteristik sosial budaya yang cenderung keras, baik secara fisik maupun psikis. Lemahnya normanorma budaya yang ada, menjadikan sikap dan perilaku sebagian etnis Madura di Semampir jauh dari kearifan dan keluhuran tata krama. Kondisi sosial seperti itu kemudian bertambah parah ketika terjadi praktik "perselingkuhan" dengan oknum aparat.

Ketiga, selainsempitnyapemahaman terhadap norma-norma agama, sistem sosial keberagamaan orang Madura di 
Semampir sering ditampakkan sebatas tradisi-seremonial yang terkadang justru dimanfaatkan sebagai alat kepentingan politik praktis oleh sebagian elite agama (kiai) demi melanggengkan pertentangan, kekerasan, dan tindakan-tindakan dehumanistik lainnya. Dengan sistem sosial keberagamaan semacam itu, maka agama tidak dapat dijadikan satu-satunya alat kontrol sosial secara maksimal.

\section{REKOMENDASI}

Berkenaan dengan praktik kekerasan yang dilakukan orang Madura di Semampir, satu hal yang menjadi kesulitan adalah bagaimana menyadarkan mereka untuk lebih mengedepankan sikap yang manusiawi ketika sedang mengalami konflik.

Dalam konteks ini, perlu adanya studi lebih lanjut tentang bagaimana menanamkan nilai-nilai berbagai budaya lokal setempat yang mencerminkan kearifan hidup bagi masyarakat Madura perantauan. Untuk langkah berat tersebut, tentu saja bukan dengan cara memangkas habis seluruh adat kultural mereka, sehingga terhindar dari kemungkinan yang lebih buruk lagi, yaitu terjadinya resistensi yang lebih kuat dan dahsyat.

Melalui hasil penelitian ini, diharapkan dapat memberikan kesadaran baru untuk melakukan pembacaan sosial secara lebih kritis terhadap nilainilai budaya dan karakter masyarakat Madura, sehingga dapat mengeliminir stigma negatif dan sikap salah sangka berlebih-lebihan terhadap komunitas etnis Madura di manapun berada.

\section{UCAPAN TERIMA KASIH}

Di akhir tulisan ini, peneliti sangat berterima kasih kepada pimpinan Fakultas Agama Islam Universitas Muhammadiyah Malang, yang telah memberikan kesempatan untuk melakukan penelitian tentang isu yang diangkat dalam artikel ini, juga beberapa pihak dan informan yang terlibat dalam penggalian data dan informasi di dalamnya. Tak lupa, terima kasih juga penulis sampaikan kepada Mitra Bestari dan Pengelola Jurnal Harmoni yang memberikan catatan dan saran untuk perbaikan tulisan ini, hingga bisa diterbitkan pada Jurnal Harmoni edisi kali ini. 


\section{DAFTAR ACUAN}

Durkheim, Emile, George Edward Gordon Catlin, John Henry Mueller, and Sarah A Solovay. (1938). 8 The Rules of Sociological Method. Free Press New York.

Faraby, Muhammad Ersya. (2016). "Etos Kerja Islam Masyarakat Etnis Madura." SALAM: Jurnal Sosial dan Budaya Syar-i 3(1): 21-38.

Faraby, Muhammad Ersya, and Siti Inayatul Faiza. (2014). “Etos Kerja Pedagang Etnis Madura Di Pusat Grosir Surabaya Ditinjau Dari Etika Bisnis Islam." Jurnal Ekonomi Syariah Teori dan Terapan 1(3).

Hidayat, Nur Azizah, and Achmad Hariri. (2017). "Analisis Solidaritas Dan Survivalitas Pedagang Madura Di Pasar Tradisional Surabaya." Trisula 2(4): 508-16.

Jafar. (2017). “Solidaritas Imigran Madura Di Perantauan Desa Jemparing Kecamatan Longikis Kabupaten Paser." eJournal Sosiatri-Sosiologi 5(1): 113-26.

Jonge, Huub de. (1995). “Across Madura Strait, The Dynamics of an Insular Society: Stereotypes of Madurese."

Jumadi. (2016). "Social Capital of Madura Barbers in Makassar, South Sulawesi." Komunitas: International Journal of Indonesian Society and Culture 8(2): 267-74.

Junaidy, Rosul. (1999). “Madura Dalam Gelombang Reformasi." Radar Madura.

Kuntowijoyo. (2002). Perubahan Sosial Dalam Masyarakat Agraris, Madura: 1850-1940. Yogyakarta: Mata Bangsa.

Mahasin, Aswab, ed. (1996). Ruh Islam Dalam Budaya Bangsa: Aneka Budaya Di Jawa. 1st ed. Jakarta: Yayasan Festival Istiqlal.

Maisaroh, Siti. Networking Etnisitas sebagai Modal Sosial Etnis Madura. Makalah Seminar Gender dan Budaya Madura III (Madura: Perempuan, Budaya \& Perubahan). http://lppm.trunojoyo.ac.id/budayamadura/diakses pada tanggal 27 September 2019.

Muthmainnah. (1998). Jembatan Suramadu Respons Ulama Terhadap Industrialisasi. Yogyakarta: LKPSM.

Rozaki, Abdur. (2004). Menabur Kharisma Menuai Kuasa: Kiprah Kiai Dan Blater Sebagai Rezim Kembar Di Madura. Pustaka Marwa.

Sasongko, Y A T, and E S Wahyuni. (2013). “Diaspora Madura: Analisis Modal Sosial Dalam Usaha Sektor Informal Oleh Migran Madura Di Kecamatan Tanah Sareal, Kota Bogor, Jawa Barat." Jurnal Sosiologi Pedesaan 1(01): 52-63.

Susanto, Edi. (2012). "Revitalisasi Nilai Luhur Tradisi Lokal Madura." KARSA: Journal of Social and Islamic Culture 12(2): 96-103.

Syamsuddin, Muh. (2018). “Orang Madura Perantauan Di Daerah Istimewa Yogyakarta.” Aplikasia: Jurnal Aplikasi Ilmu-ilmu Agama 18(1): 1-22.

Taufiqurrahman. (2012). "Identitas Budaya Madura." KARSA: Journal of Social and Islamic Culture 11(1): 1-11.

Wiyata, A Latief. (2002). Carok; Konflik Kekerasan \& Harga Diri Orang Madura. Lkis Pelangi Aksara. 